\title{
The Effect of Age and Educational Level of Owner/Managers on SMMEs' Access to Bank Loan in Eritrea: Evidence from Asmara City
}

\author{
Sebhatu Kefleyesus Ogubazghi, Willy Muturi \\ Economics, Finance and Accounting Department, Jomo Kenyatta University of Agriculture and Technology, \\ Main Campus, Juja, Kenya \\ Email: oksebhatu@yahoo.com
}

Received 24 September 2014; revised 28 October 2014; accepted 7 November 2014

Copyright (C) 2014 by authors and Scientific Research Publishing Inc.

This work is licensed under the Creative Commons Attribution International License (CC BY). http://creativecommons.org/licenses/by/4.0/

c) (i) Open Access

\begin{abstract}
The general objective of this study was to find out the influence of owner/manager characteristics on SMEs' access to bank loan. A sample of 87 small and medium manufacturing enterprises was drawn from Asmara city using proportionate systematic sampling. A reliable primary data was collected through semi structured and structured questionnaires which were personally administered by the researcher. Descriptive and econometric statistical analysis techniques were used to analyze the data. The study, using logistic regression, found out that age of the owner/manager has significant effect on SMMEs' access to bank loan. On the other hand, educational level of the owner/manager does not have significant effect on access to bank loan. Both the variables have positive effect on SMMEs' access to bank loan.
\end{abstract}

\section{Keywords}

Access to Bank Loan, Eritrea, Human Capital, Logit, Owner/Manager Characteristics, SMEs

\section{Introduction}

Poverty trap has been the main challenge for young developing countries, like Eritrea. The development, growth and prosperity of SMEs contribute to the poverty alleviation [1], by creating employment, strengthening economic growth, creating diversified economic or industrial base, laying foundation for industrialization, encouraging entrepreneurship, innovation and competition, and installing equitable income distribution and social stability. Therefore, it is not surprising to observe SMEs attracting interest from policy makers, academics, practitioners, and the general public. In various studies employment and GDP have been considered as the two major 
indicators that can explain the economic and social significance of SMEs [2]. According to IFC Issue Brief on SMEs of 2013 [3], SMEs account for about $90 \%$ of businesses and more than $50 \%$ of employment worldwide. SMEs contribute 33 percent to the GDP of developing countries [4]. This shows that it is not a fad or overemphasis to dub SMEs as bloodline and backbone of an economy [5]-[7]. However, despite their significance, SMEs contribution hasn't been socially and economically optimal due to various obstacles [8]. Significant literature review identified constrained access to finance as one of the top ranked obstacles for SMEs. For example, World Bank Enterprise Survey (2013) [9], with a survey of 130,000 firms in 135 countries, found out that limited access to finance ranked at the top of the list of obstacles to growth and development of small and medium enterprises. The problem of accessing finance is much worse in the Sub-Sahara Africa Countries which constrained the development and growth of SMEs [10].

Both internal and external financial resources are necessary for SMEs to be able to grow, expand, develop and prosper [11]. SMEs heavily rely on internal finance. However, the entrepreneur's own and family accumulated wealth often appear to be limited to cover all the financing needs of their business [12]. Moreover, the poor performance and the unstable income of SMEs also make internal financing challenging [13]. This prompts the increasing demand for external sources of finance. However, several empirical evidences (such as: Pandula, 2011 [12]; Berger and Udell, 1998 [14]; Beck and Demirguc-Kunt, 2006 [15]) witnessed that accessing external finance is still a challenge for small firms than it is for large firms. This problem is globally true, but it is worse in the case of developing countries [10].

In finance literature it is widely documented that external finance is generally composed of both equity and debt. The external equity market of developing countries is inefficient, particularly for SMEs and this makes it difficult for SMEs to access external equity. This explains why SMEs depend on debt, particularly bank loan. Several scholars (such as: Abor and Biekpe, 2007 [16]; Demirgüç-Kunt et al., 2008 [17]; Fatoki and Odeyemi, 2010 [18] etc.) have suggested that Bank credit finance is the major source of external finance next to internal finance for SMEs. Banks' ability to provide credit services for businesses whose balance sheet lack sufficient transparency, suitable lending technology and relatively lower lending cost (compared to informal sources of finance) places them in a position to dominate the external finance market for SMEs (Craig, Jackson, and Thomson, 2005) [19]. Despite this fact, plethora of empirical evidences shows that SMEs survival and growth has been threatened due to constrained access that such firms have to bank credit (Abor and Biekpe, 2007 [16]; Fatoki and Asah, 2011 [20]; Canton, Grilo, Monteagudo and van der Zwan, 2012 [8] etc.). The availability (in terms of quantity and quality) and accessibility of bank loan by economically significant SMEs are less than what is considered socially and economically optimal [8].

A firm's access to bank loan can be affected by macro-environmental factors, supply side factors and demand side factors [21]. This study focused on factors that affect firms' ability and desire to access bank loan. One of these factors is the characteristics of owner/manager. Considering the major and dominant role the owner/manager plays in SMEs, the importance of considering the effect of owner/manager characteristics on access to bank loan is logical.

This study examined the human capital determinants of access to bank loan of SMMEs in Asmara city, the capital of Eritrea. Eritrea is a small young independent country and is located at the horn of Africa. This study attempted to address two major research gaps in the extant literature. There is paucity of researches that cover the effect of the owner/manager characteristics on access to credit [22]. But recently, the interest of scholars and policy makers on the effect of owner/manager characteristics on SMEs' access to bank loan has been increasing. However, the result of the studies conducted on this area showed mixed results [5]. In addition, most of the extant studies focus in developed world; the developing world has been given less emphasis. Several studies indicate that the small firms in developing Sub-Saharan African countries are facing more constrained access to credit, compared to other regions. To the best knowledge of the author of this study, there is no systematic study on the effect of the characteristics of entrepreneurs on bank credit finance in Eritrean. Besides, young countries, with underdeveloped institutional infrastructure and economy, have their own specific shared developmental challenges. This is mainly because they have similar situations, some of which include limited income and being in continuous war conflicts. Lack of unconstrained access to finance for SMEs is one of the shared characteristics by least developed countries.

In addition, in the extant empirical literature, there is no consensus on the effect of the human capital variables on access to bank loan. To fill these gaps, the study employed a logit regression analysis, to analyze the effect of age and education of owner/manager on SMEs ability and desire to access bank loan. This study used 
firm-level survey data constructed from 84 Small and Medium Manufacturing Enterprises (SMMEs) in Eritrea (out of a sample of 87 SMMEs). The variation in the sample was tested to identify the effect of the variation of owner/manager characteristics on access to bank loan.

The remaining part of the paper is structured as follows: first SMEs are defined and then, the next part is dedicated to the literature review which summarizes the main relevant theories and the researches undertaken so far on this area. Then, the following section discussed the methodology. The findings of the data are presented and followed with conclusion and the measures that need to be taken in order to improve SMEs' access to finance.

\section{Literature}

\subsection{Definition of Small and Medium Enterprises}

Several studies have attempted to define SME as a term that covers a wide range of definitions, roles and measures. The definition for SMEs varies from country to country, from one source of report to another and from one financial institution to another. It is contextual, and there is no universal definition for SMEs [23]. The definition, most of the time, is based on criteria or cut offs such as the number of employees, the value of sales, and/or the value of assets. Even the criteria and the measures vary from country to country and from institution to institution. In Eritrea, number of employees is used as a cut-off to classify the sizes of firms. SMEs in Eritrea are generally defined as firms which have minimum 5 and maximum 25 numbers of employees. This definition is established with the agreement of Ministry of Trade and Industry of Eritrea and United Nations Industrial Development Organization to fit the situation of least developed countries. The study was conducted on registered and independent Small and Medium Manufacturing Enterprises SMMEs in Asmara city, Eritrea.

\subsection{Theoretical Framework}

There hasn't been any standard theoretical framework which deals with SMEs financing patterns. There has been increasing effort to identify and investigate the factors that determine the accessibility of bank loan by SMEs [5] [24]. This section will attempt to give overview of the general assumptions and related theory, and explore factors that affect SMEs' ability and desire to borrow from bank.

Irwin and Scott (2010) [22] suggested that SMEs' problem of constrained or lack of access to credit emerges from the owner/managers preferences and bank's risk aversion. The problem of SMEs' financial exclusion can also be viewed into twofold or dichotomy: voluntary and involuntary financial exclusions [17]. These two perspectives are mostly the same and are built around the two major parties which involve in credit decision making: the borrower (owner/manager of the SME) and the lender (bank). Both approaches are capable to show how the characteristics of the owner/manager affect access to bank loan from both the borrower and lender perspective. From the lender perspective, SMEs are not attractive to banks and thus, are involuntarily excluded (discriminated) from accessing bank credit [25]. Banks' perceive SMEs as an unattractive portfolio in terms of risk aversion; this perception is partly linked with the characteristics of the owner/managers [26]. There are also situations where SMEs voluntarily exclude themselves from accessing bank services. The characteristics of the owner/manager, among many other factors, are strongly correlated with the decision and behavior of the owner/ manager [22].

Fernando, Chakraborty and Mallick (2002) [27] identified that owner/manager characteristics can be considered as the critical factor that influences the banks decision on lending to SMEs. Beck (2011) [28] (cited Joseph Schumpeter, 1911) indicated that financial intermediaries have the discretion to channel the society's savings to borrowers they choose. The choice of banks depends on the interest rate they receive from the loan and riskiness of the borrower [29]. Interest rate depends on the riskiness of the enterprise and/or the project. However, too much dependence on interest rate to compensate for increasing risk promotes moral hazard and adverse selection [29] [30]. In an attempt to reduce adverse selection and moral hazard, banks use other means to screen risky borrowers (portfolios). Banks collect information that can indicate the borrowers' future behavior. Banks are interested in knowing whether the borrower is willing and capable to pay the principal plus the interest at maturity date. However, information on SMEs is hard to find. Banks, through various lending technologies, collect information on the borrower to assess the borrowers' creditworthiness, as much as it is possible [31]. Such information can be soft information (information that cannot be summarized into numerical formats i.e. qualitative information) or hard information (quantitative information like financial reports) [32]. As it is stated earlier, 
SMEs are opaque firms which lack information that have the feel of hard information (financial information disclosure and credit track record). This leaves banks to heavily rely on soft information to assess their SME clients' creditworthiness. Banks, having superior ability to collect and process information, are best placed in lending to opaque borrowers like SMEs [32]. To overcome the problem of opacity of SMEs and reduce the effect of information asymmetry, banks go further beyond the readily available information to assess the creditworthiness of the borrowers. This eases SMEs' constraints to access bank loan [33]. Several studies considered information on characteristics of owner/manager and firm as valuable input for bank to assess the creditworthiness of firms, particularly in the case of SMEs.

In addition to the above perspective, from demand side perspective, the characteristics of the owner/manager also shape the owner/manager's preference and behavior which is critical in determining SMEs' desire and decision to access bank loan [22]. Mukiri (2008) [24] stated that owner/manager characteristics indirectly determine the firm's access to bank loan indirectly through manager's orientation. This becomes clear when we look into some managers who could have benefited from the finance offered by banks fail to seek and secure this proffered credit service. Some may utilize this credit service more than others, and some may not utilize it at all.

Discussing the different scenarios of situations in lending and borrowing relationship can give good perspective of the subject matter. If the manager does not want to access bank loan, there must be a reason for this. Some of these reasons include: not willing to share control and information, availability of sufficient internal fund, and not having adequate information and experience on matters pertaining accessing loan. Because of these reasons and others, owner/managers prefer one source of finance over the other. Owner/managers with particular characteristics tend to prefer particular source of finance [22].

In addition, there are also situations where owner/managers, may seek finance, but fail to apply for loan thinking that they will be rejected or cannot meet the conditions and terms of the loan. Such borrowers are known as "discouraged borrower" and these borrowers consider the application cost in deciding on whether to apply or not [34]. This means borrowers refrain from applying for a loan to save the costs of application because of possible rejection. The characteristics of the owner/manager can influence the perception this particular individual has about the possible success or rejection of the loan application.

In yet another scenario, the owner/manager may seek and apply for bank loan. However, it is the banks behavior and decision which determines the firm's access to bank loan. Such decisions are mainly influenced by the perception that a bank may have about the characteristics of the owner/manager, especially in the case of SMEs lending. In addition, the experience and knowledge of the owner/manager about the requirements of acquiring such finances at a particular point in time has critical impact on a firm's access to bank finance.

\subsection{Asymmetric Information Theory}

This theory is instrumental to understand the reason behind SMEs' constrained access to finance. It explains that this comes from the fact that the owner/managers (insiders) have more information than the banks (outsiders). Zoppa and McMahon (2002) [35] (cited Scherr et al., 1993) indicated that such asymmetry of information puts the burden of high cost on firms with high information asymmetry. As mentioned above SMEs have high information asymmetry. This information asymmetry makes financing SMEs from external sources difficult. In addition, the unavailability of readily available financial information forces banks use owner/manager characteristics to assess the creditworthiness of borrowers.

\subsection{Human Capital Theory}

Human capital can generally be defined as intellectual resource or relevant experiences which influence access to finance. The human capital of SME owners comprises quality of basic and vocational education and quality work experience, among other elements [36]. Since it is difficult to measure quality of human capital variables, numbers of years or levels are commonly used to measure the variables of human capital. Human capital theory suggests that difference in the human capital of owner/managers of SMEs can explain why some SMEs access bank loan more than others.

\subsection{Resource Based Theory (RBT)}

RBT is a strategic management theory which asserts that firms are endowed with idiosyncratic, immobile, inimitable, complex, dynamic and sometimes intangible resources. It is commonly used to analyze the relationship 
of a firm resources and its performance. It can also give insight in firm’s ability to access finance. Resources are inputs by which a firm achieves its objective. Resources are commonly classified as human capital, social capital, physical capital, financial capital, organizational capital and process capital resources. Human capital is one of the resources around which firms build their competitive advantage. RBT, therefore, can be used to examine how owner/manager individual-specific characteristics serve as a competitive advantage to improve a firm's accessibility to finance. Mukiri (2008) [24] used Resource Based Theory to explain the accessibility of bank loans by SMEs.

The above theoretical framework laid a foundation to analyze and understand the effect of the owner/manager's characteristics on the latent behavior of the business and bank in determining the accessibility of bank loan by SMEs.

\subsection{SMEs' Access to Bank Credit}

For the purpose of this study, SMEs' access to bank loan is defined as the ability and desire of SMEs' owner/manager to obtain bank credit. SMEs particularly in developing and least developing countries have constrained or lack access to bank loan. Bank loan is one of the major sources finance of SMEs. However, there are empirical evidences which indicated that the survival and growth of SMEs is questioned because of the lack of finance.

Most of the studies conducted in this area found that SMEs have limited or lack access to bank loan. Generally SMEs, in developing country, have much lower likelihood of accessing bank loan than larger firms (World Bank, 2010) [4]. In a survey study of Tanzanian SMEs, Kira (2013) [6] found out that 76.5\% of all small firms which applied for debt financing were rejected; followed by Medium firms, $19.8 \%$ of medium firms applied for a loan were rejected while only $3.7 \%$ of large firms applied for loans were rejected. This same study also demonstrated how hard it is for SMEs to access bank loan by indicating that SMEs $96.3 \%$ of the firms whose application was rejected were SMEs. In addition, it showed that 76.5\% of small firms, $19.8 \%$ of medium firms and $3.7 \%$ of large firms' loan application were rejected. Fatoki and Odeyemi (2010) [18], with a sample of 406 South African SMEs, found almost similar result, that is $72.4 \%$ of the SMEs which had applied for loan from commercial bank were rejected. Mukiri (2008) [24] discovered that only $7.8 \%$ from the sample of 218 small scale manufacturing enterprises in Kenya had accessed bank loan with in the last twelve months. As it is supported by the empirical evidences, whether it is voluntary or involuntary, SMEs have lower likelihood to access bank loan.

\subsection{Owner/Manager Specific Characteristics}

As aforementioned, there are several factors that affect SMEs' access to bank loan. However, this study will focus on only one of these group factors and this is owner/manager (individual) specific characteristics. The rationale for the study to emphasize on owner/manager characteristics is based on the fact that SMEs are dependent more on the ability and desire of a single individual or few individuals to access finance [37] [38].

In the recent decades there has been increasing empirical studies on the effect of owner/manager characteristics on SMEs' access to bank loan. For the purpose of this study, owner/manager characteristics are defined as those traits or attributes that are specific to the owner/manager of the firm which can influence access to finance of the firm negatively or positively. Neneh, (2011) [39] indicated that previous studies have classified characteristics of entrepreneur into five categories as trait, demographic/social characteristics, behavioral/managerial characteristics, economic characteristics and human capital characteristics. Islam, Khan, Mohammad, Obaidullah and Alam, (2011) [40] also used a similar categorization of the variable: demographic characteristic, individual characteristic, personal traits, entrepreneur orientation, and entrepreneur readiness as owner/manager characteristics. From these lists of factors, only human capital characteristic of owner/managers was considered in this study. Some of the commonly identified characteristics under these categories include age, ethnic group affiliation, religion affiliation, culture, educational level, experience of the owner in various areas, networking etc. This study further narrowed its focus on age and educational background of the owner/manager.

There is copious literature which suggests age and educational level have significant effect on SMEs' access to finance. However, there are also some other studies which found that there is no significant relationship between these variables. Nguyen and Luu (2013) [5] indicated that there has been a mixed result of studies on the effect of these factors on access to bank loan and the result vary across countries. 


\subsection{Age of the Entrepreneur}

Age is one of the most commonly studied factors that affect access to bank loan. The effect that age has on access to bank loan can be viewed from both demand and supply side of loan. From the perspective of demand side, age is a factor that determines the owner/manager's preference or self-selection of either being user or non-user in the credit market [41] [42]. This is based on the assumption that a particular age group tends to behave and prefer in a different way than other age groups. For instance, older owner/managers commonly appear to be risk [41] and do not want to use bank loan. The motivation of entrepreneurs also varies with age. For instance old entrepreneur motivation to run a business often appears to be just a hobby or monopoly of power. Such individuals tend to fail to attract, apply or secure external finance. Similarly, from supply side perspective, banks' perception of different age group also affects access to bank loan. For instance, entrepreneurs of old age group are generally perceived as non-innovative and non-dynamic. Young aged owner/managers are perceived as innovative and good performers, but risky portfolio. In addition, Abdulsaleh and Worthington (2013) [42] observed that information asymmetry decreases as the age of owner/managers increases and lead to an improved access to bank loan. Therefore, there are some implicit and explicit implications which can affect the decision of both the lender and borrower.

There are several studies that investigated the effect of age on access to finance, however there are mixed results, mainly on the significance of the variable. A study conducted by Nguyen and Luu (2013) [5], Fatoki and Odeyemi (2010) [18] and Nguyen and Luu (2013) [5] showed that age do not have significant effect on access to finance. Slavec and Prodan (2012) [43] also found out that age and debt financing do not have significant relationship. However, contrary to the above findings, Nguyen and Luu (2013) [5] demonstrated that age have significant effect on the studied firms' ability to access finance. As it can be concluded from the above discussion, the results of the studies on this factor have mixed result, more particularly with regard to its significance. The result on the direction of the effect that age has on access to bank loan is also mixed. However, Abdulsaleh and Worthington (2013) [42] suggested that the positive effect of age on access to credit prevails over the negative effects.

H0Age: Age of the owner/manager has no significant effect on SMEs’ probability of accessing bank loan.

\subsection{Level of Educational of the Manager/Owner}

In some studies (like Kasseeah \& Thoplan, 2012) [44], educational level is measured with ordered category as primary level, secondary level, tertiary level etc. But in this study it will be measured with the number of years the owner/manager attended school, as continuous value.

There are several studies which concurred with the opinion that the quality of human capital increases as the years the owner/manager spent in school or training increases. From the perspective of the supply side, banks perceive owner/manager with higher educational qualification as creditworthy [42]. Therefore, such entrepreneurs have higher likelihood of accessing bank loan than those who don't have. These authors also suggested that educated owner/manager have confidence to overcome obstacles of accessing bank loan and relatively well informed on bank credit services and its requirements. Thus, it is more likely that such individuals tend to apply for loan than others with lower educational qualification.

Zarook et al. (2013) [45] and Slavec and Prodan (2012) [43] discovered that educational level of owners have significant positive correlation with access to bank loan. Ahmed and Hamid (2011) [13] used the top manager's level of education as a measure of the quality of human capital and found significant positive relationship between educational level and the probability of accessing bank finance. Pandula (2011) [12] also obtained a result that shows that educational background has significant relationship with access to bank loan. Nguyen and Luu (2013) [5] treated education into three different variables, namely: basic educational level, professional educational level and knowledge about Enterprise law and Tax law. This study showed that all these proxies of educational qualification of the owner/manager have significant positive effect on access to finance. Mukiri (2012) [24] investigated the effect of educational level and training on access to bank loan indirectly through entrepreneurial orientation. The author found that educational level of the entrepreneur has positive effect on access to finance. Kira (2013) [6] established that SMEs with owner/manager who have educational qualification of vocational level and beyond are more likely to be favored by banks to access credit. Le et al. (2006) [46] identified that there is strong effect of educational level on networking. The author also showed that networking influences firms' accessibility to bank financing. To the contrary, Abdesamed and AbdWahab (2012) [2] by using logit re- 
gression discovered that educational level of the owner/manage has positive but found insignificant influence on firms' access to bank loan at startup. As it is displayed in the above discussion, there is no consensus on the significance of the effect that educational level of the owner/manager on access to bank loan.

HOEdl: Difference in educational level of the entrepreneur has no significant effect on SMEs' probability of accessing bank credit.

The above discussion shows that there is research gap throughout the subject. As it can be observed in the empirical literature review, since there is no standard framework, the set of variables considered varies from study to study. How the variable is measured also vary across different studies that made comparison impossible. Most of the studies followed a general focus on access to finance rather than on access to bank loan. Research results reviewed shows that there has been mixed results which calls for more research interest to further investigate the effect of the characteristics of the owner/manager on access to bank loan.

\section{Research Methodology}

With respect to the methodological choice for this study, a qualitative approach was used. This empirical study investigated on how characteristics of owner/manager(s) affect access to bank loan. To test the hypotheses properly, survey questionnaire was prepared and tested, then used to collect data from SMMEs in Asmara. Using a formula from raosoft.com website [47], from a population of 746 SMMEs, a sample of 87 SMMEs were obtained to make inference on the population. The sample was drawn from list of registered and independent SMMEs acquired from the data base of Registration Office of Ministry of Trade and Industry. The sample was drawn using proportionate systematic sampling.

This study aimed to analyze which of the hypothesized regressors significantly affect the SMEs' access to bank loan. There are two possible situations; a firm: (1) may access bank loan or (2) may not access bank loan. Therefore, the dependent variable is categorical. In such situations, qualitative binary response model (QBRM) is appropriate [48]. Ordinary least square model (OLSM), Probit regression Model (PRM) and Logistic Regression Model (LRM) are the three major QBRMs. For this study LRM was used. LRM's estimated probability lies with the range of 0 to 1 , while OLS has a serious defect in that the estimated probability values can lie outside the normal 0 to 1 range. LRM and PRM have been used in traditional researches which dealt with SMEs' access to finance [49]. LRM and PRM produce similar results. Various studies (like Cox, Hand and Herzberg, 2005 [50] and Horowitz and Savin, 2001 [48]) indicated that Logit and probit analysis are the most widely used methods for estimating the effects of the variation of attributes of individual decision makers on two different choices. In deciding which of these two models to use, a convenience and conventional choice should be employed [51]. However, Hosmer and Lemeshew (1989) [52] advocated that LRM is easy and flexible to use and provides meaningful interpretation. Therefore, this study will employ LRM to make a rigorous analysis on the effect that the owner/manager characteristics has on determining the probability that an SME accesses bank loan.

Participant owner/managers of SMEs were asked to volunteer for a study. Qualitative and quantitative data was collected using a survey questionnaire which includes structured and semi-structured questions. Information on the variables was collected and input into SPSS, a statistical software package. The data collected was analyzed using logit regression model, in order to test the research hypothesis for this study. Descriptive statistics analysis was also conducted. The dependent variable is SMEs' access to bank loan. The independent variables include management experience and educational level.

To initiate the modeling, the relationship between the independent and dependent variables was formed as follows.

$$
\operatorname{Probability}\left(Y=1 \mid X_{i}\right)=P(Y)=\frac{1}{1+\exp ^{-\left[\alpha+\sum_{i=1}^{k} \beta_{i}\left(X_{i}\right)+\varepsilon_{i}\right]}}=\frac{1}{1+\exp ^{-\left[\alpha+\beta_{1}\left(X_{1}\right)+\beta_{2}\left(X_{2}\right)+\varepsilon_{i}\right]}}
$$

where: $\mathrm{Xs}$,

$P(Y)$ denotes the probability of the outcome of interest or success or event given the explanatory variables

$\beta_{i}$ are the parameters are the regression coefficient determine the location, slope and spread of the curve, for respective variable at each observation,

$X_{i}$ the variable at each observation ( $\mathrm{X}_{1}=$ Management Experience, $\mathrm{X}_{2}=$ Educational Level ). It is categorical or continuous or both, 
$\alpha$ is the $Y$ intercept,

$\varepsilon_{i}$ error term-assumed as the disturbance parameter $\varepsilon$ has normal distribution,

$\operatorname{Exp}=2.71828$ is the base of the system of natural logarithms.

A firm's access to bank loan can be noted from the capital structure of a firm in the balance sheet. However, SMEs, more specifically in developing countries, do not maintain proper accounting information. Therefore, it is difficult to measure or capture SMEs' access to bank loan from balance sheet. In such situations, perception based survey study is used by collecting data from the perception of the owner/manager.

$Y$ represents access to bank loan of a firm. It is a dummy variable and takes binary value. If the observed SME has access to bank credit, the dependent variable $Y$ takes on the value of " 1 ”. If the SME has unconstrained access to and/or use bank finance, the dependent variable $Y$ takes on the value " 0 ". This variable will take " 1 " when the following two conditions are true: (1) If the firm has not applied for loan either because the manager thinks his/her application will be rejected (discouraged borrower) or if he/she does not want to take loan or not aware and (2) If the owner applied but was rejected or has received an amount less than claimed; otherwise it will take " 0 ". Age $\left(X_{1}\right)$ is a continuous variable and is measured in terms of the number of years the owner/manager lived. Educational level $\left(X_{2}\right)$ is a continuous variable and is measured in terms of the number of years the owner/manager spent studying or being trained.

\section{Result and Discussion}

After the text edit has been completed, the paper is ready for the template. Duplicate the template file by using the Save As command, and use the naming convention prescribed by your journal for the name of your paper. In this newly created file, highlight all of the contents and import your prepared text file. You are now ready to style your paper.

The study focused on SMMEs establishments operating in Eritrea. A sample of 87 SMMEs was first drawn using proportionate systematic sampling and questionnaires were administered, carried out between months of March and April 2014. Finally, only 84 out of 87 questionnaires were collected i.e. 96.55\% response rate. The firms in the sample are from different economic sub-sectors. The respondents include from SMMEs in food processing industry (27.38\%), non-metallic mineral industry (8.33\%), metal industry (9.52\%), furniture industry (38.10\%), paper and printing industry (2.38\%), leather and leather product industry (3.57\%), beverage industry (0\%), textile industry (5.95\%), and plastic and rubber industry (1.19\%).

\subsection{Descriptive Results and Analysis}

Overall 87 survey questionnaires were distributed and 84 firm's owner-managers participated in the study and the distributions of the businesses in the industry in terms of access to finance, and owner/manager characteristics were investigated. Almost all (80.95\%) of the SMMEs in Asmara city have never accessed bank loan since their start up. $52.94 \%$ of the $19.05 \%$ of the respondents accessed bank loan accessed it before six or more years, the remaining accessed it with in the past five years. When access to finance was measured within the last five years, the study found that only $9.52 \%$ of the sampled firms have accessed bank loan within the last five years, while the remaining $90.48 \%$ did not access or have constrained access to bank loan within this time frame. The study also found out that $16.67 \%$ wanted to access loan and applied for it. More than half of these respondents (57.14\%) received the entire amount of loan they applied for. This is not surprising, considering that only about one sixth of the sample applied for loan. From those who had applied, $21.43 \%$ failed to get loan because they were not able to meet the requirements or terms and conditions presented to them. Collateral requirement, which is $100 \%$ in most instances, makes up the major constraint for SMMEs to access bank loan. Rejection of loan applications by bank accounted to $7.14 \%$ of the respondents who had applied. The remaining $14.29 \%$ of the respondents either do not have knowledge about the status of their loan application or don't want to give response.

The sample includes respondents from different age group and from different sectors. The youngest owner/ manager interviewed was aged 22 years whilst the oldest was aged 87 years with a mean age of 49.87 years and standard deviation of 15.352. 75\% of the respondents lie below 61 years of age. The remaining $25 \%$ are 61 years of age and beyond. $8.33 \%$ of the respondents were of the age bracket of below 30 years of age, 25\% were between the ages of 31 - 40, 21.43\% were between 41 - 50, 20.24\% were between 51 - 60, 13.10\% were between 61 - 70 while $11.90 \%$ were between the ages of $71-87$.

Academic qualification of the respondents varies from having no educational background to 18 years of edu- 
cation, with average of 9.24 years and standard deviation of 4.083. The average of educational level for those who accessed bank loan (9.25) is a little bit higher than those who didn’t access bank loan (9.03). 66.67\% of the respondents have educational qualification of high school and above, while the $33.33 \%$ respondents were below high school.

\subsection{The Logit Regression Results}

The variables obtained from the survey were tested for their effect on access to debt financing. Two independent variables were regressed with access to bank loan. The results of the logit regression analysis of the effect of the human capital variables on the probability of the SMMEs' access to loan are illustrated in Table 1 . The results indicate that age of the owner manager have significant effect on access to bank loan. On the other hand educational level of the owner/manager is not significant determinant of the SMMEs' access to bank loan at $5 \%$ level of significance.

The data for the dependent and independent variables used in the regression analysis were collected from the primary data from field survey. The two independent variables were entered together at one step.

$$
\operatorname{Probability}\left(Y=1 \mid X_{i}\right)=\frac{1}{1+\exp ^{-\left[-9.710+0.104\left(X_{1}\right)+0.172\left(X_{2}\right)+\varepsilon_{i}\right]}}
$$

Given the constant and the coefficients of the variables of the above model, a change in the value of the variables $\left(X_{1}\right.$ and $\left.X_{2}\right)$ changes the value of $\operatorname{Probability}\left(Y_{i}\right)$. By entering the value of each variable the probability that an SMME may access or not can be determined by this model.

\subsection{Age of the Owner/Manager}

The coefficient for age of the owner/manager (0.104) was positive. Age was statistically significant and this means the null hypothesis is rejected. The odd ratio for age is 1.109 with a p-value 0.007 . If age of the owner/manager increases by 1 unit, that is one year, then the odds ratio of the age of the owner/manager is 1.109 times as large and therefore, SMMEs are 1.109 times more likely to access bank loan. Consistent with this study Mukiri (2008) [24] and Nguyen and Luu (2013) [5] showed that age makes significant effect in determining the access to bank loan. Contrary to the finding of this study, the study conducted by Nguyen and Luu (2013) [5] Fatoki and Odeyemi (2010) [18], and Slavec and Prodan (2012) [43] showed that age do not have significant effect on access to finance.

\subsection{Educational Level of the Manager/Owner}

The coefficient of the educational level owner/manager (0.172) was positive and statistically significant and confirms the study's hypothesis. The odd ratio for educational level is 1.188 with a p-value 0.104 . This signifies that the effect that educational level on SMMEs' likelihood to access bank loan is not strong. Therefore, results comply with Fatoki and Odeyemi (2010) [18], Abdesamed and AbdWahab (2012) [2] and Irwin and Scott (2010) [22] which discovered that educational level of the owner/manager do not make much difference in determining SMEs' access to bank loan. Contrary to the result of this study, Fatoki and Asah (2011) [20], Ahmed and Hamid (2011) [13], Kira (2013) [6], Pandula (2011) [12], Zarook et al. (2013) [45] and Slavec and Prodan (2012) [43] discovered that educational level of the owner/manager have significant impact on access to bank loan.

Table 1. The logit binary regression analysis results.

\begin{tabular}{cccc}
\hline \multirow{2}{*}{ Variables } & \multicolumn{3}{c}{ Table Column Head } \\
\cline { 2 - 4 } & Coefficients & Significance & Odds Ratio \\
\hline Age & 0.104 & $0.007^{\mathrm{a}}$ & 1.109 \\
Education & 0.172 & 0.104 & 1.188 \\
Constant & -9.710 & 0.002 & 0.000 \\
\hline
\end{tabular}

${ }^{\mathrm{a}}$ Significant at 5 percent level of significance. 


\section{Implication, Conclusion, Recommendation and Suggestions of the Study}

\subsection{Implication of the Study}

There is an important policy implication of understanding access to debt by different sub-categories of small and medium manufacturing businesses' owners, based on different characteristics of owner/managers. Since access to credit, as demonstrated in this study, differs across different groups of owner/managers, policy intervention will be more effective when customized to specific groups of SMMEs (specific owner/manager characteristics). The behavioral deference of owner/managers in accessing bank loan at firm level are associated with differing owner/manager characteristics that varies across different groups (based on the characteristics) of owner/managers. This study explored the impact of owner/manager specific factors on access to bank loan financing which will enable policy makers, financial institutions and SMEs to formulate proper measures to encounter firms’ financing obstacles.

\subsection{Conclusion and Recommendation of the Study}

SMEs are core to solve both economic and social problems of a society, i.e. poverty trap, which is growing in Eritrea and other developing countries. However, due to lack of finance, SMEs' contribution is not economically and socially optimal. The study explores what can determine bank loan financing constraint to a firm by investigating owner/manager characteristics: age and educational level, as having an influence on access to debt financing by SMEs in Eritrea.

The analysis in this study indicates that age has significant effect on determining the likelihood that SMMEs access bank loan, at 5\% level of significance. Hence the null hypothesis with regards to this determinant is rejected. On the other hand educational level does not have significant effect on the probability that SMMEs access bank loan, therefore the null hypothesis with respect to this determinant is accepted. Both age and educational level have a positive effect on the SMMEs' probability of accessing bank loan. The study found out that most of the firms managed by young owner or professional manager encounter difficulties to access debt financing. Accordingly, policies, strategies and programs have to be forged to cope with the needs of SMEs. In the case of this study, age was found to have significant effect on access to bank loan. Therefore, policy makers, banks, and other development partners should promote young owner/managers.

\subsection{Limitations and Suggestions for Further Researches}

Due to time and budget limitation, the focus of this study is narrow and the factors considered are very few and the research area is restricted to Asmara city. This constricts the study from providing general and comprehensive solution to all SMEs in Eritrea. Future research should consider a full-fledged research that considers other factors and cover the whole country. This research was based cross sectional data, rather than time series, and this limits the validity of casual links of the results. Longitudinal research on how owner/manager characteristics affect SMEs' access to bank loan is necessary. In addition, this study used the perception of the owner/manager to measure access to bank loan and this limited the result of the examination of the effect of the owner/manager characteristics on access to bank loan. Therefore, in the future, researches should include other measures of bank financing as well, such as balance sheet information about the level of debt. There is limited availability of statistical data regarding the factors that determine SMEs' access to bank loan from various countries, including Eritrea. This imposes certain limitations to the researches in this field. Such limitations can be overcome as policy makers realize the vital importance of developing and monitoring specific indicators regarding the financing of this type of enterprises.

\section{References}

[1] Hallberg, K. (2001) A Market-Oriented Strategy for Small and Medium-Scale Enterprises. Washington DC.

[2] Abdesamed, K.H. and Abd Wahab, K. (2012) Do Experience, Education and Business Plan Influence SMEs Start-Up Bank Loan? The Case of Libya. Australian Journal of Basic and Applied Sciences, 6, 234-239.

[3] IFC (2013) IFC Issue Brief/Small and Medium Enterprises. Washington DC.

[4] World Bank (2010) Scaling-Up SME Access to Financial Services. Washington DC.

[5] Nguyen, N. and Luu, N. (2013) Determinants of Financing Pattern and Access to Formal-Informal Credit: The Case of 
Small and Medium Sized Enterprises in Viet Nam. Journal of Management Research, 5, 240-259. http://dx.doi.org/10.5296/jmr.v5i2.3266

[6] Kira, A.R. (2013) The Evaluation of the Factors Influence the Access to Debt Financing by Tanzanian SMEs. European Journal of Business and Management, 5, 1-24.

[7] Ahinful, G.S. (2012) An Exploration of the Problems Facing SMEs in Securing Bank Financing in Kumasi, Ghana. International Journal of Business and Management Cases, 1.

[8] Canton, E.J.F., Grilo, I., Monteagudo, J. and van der Zwan, P. (2012) Perceived Credit Constraints in the European Union. Erasmus Research Institute of Management (ERIM), ERIM Report Series Research in Management ERS-2010001-ORG, Rotterdam, 29 October 2012.

[9] World Bank (2013) Enterprise Surveys News Release. http://www.enterprisesurveys.org

[10] Fjose, S., Grünfeld, L.A. and Green, C. (2010) SMEs and Growth in Sub-Saharan Africa-Identifying SME Roles and Obstacles to SME Growth. MENON Business Economics, MENON Publication No. 14/2010, Oslo, Norway.

[11] European Commission of Enterprise and Industry (2009) Cyclicality of SME Finance Literature Survey, Data Analysis and Econometric Analysis. European Community, Aoetmeer.

[12] Pandula, G. (2011) An Empirical Investigation of Small and Medium Enterprises’ Access to Bank Finance: The Case of an Emerging Economy. ASBBS Annual Conference, Proceedings of ASBBS, Las Vegas, 18, 255-273.

[13] Ahmed, H. and Hamid, N. (2011) Financing Constraints: Determinants and Implications for Firm Growth in Pakistan. The Lahore Journal of Economic, 16, 317-346.

[14] Berger, A.N. and Udell, G.F. (1998) The Economics of Small Business Finance: The Roles of Private Equity and Debt Markets in the Financial Growth Cycle. Journal of Banking and Finance, 22, 613-673.

[15] Beck, T. and Demirguc-Kunt, A. (2006) Small and Medium-Size Enterprises: Access to Finance as a Growth Constraint. Journal of Banking and Finance, 30, 2931-2943. http://dx.doi.org/10.1016/j.jbankfin.2006.05.009

[16] Abor, J. and Biekpe, N. (2007) Small Business Reliance on Bank Financing in Ghana. Emerging Markets Finance \& Trade, 43, 93-102. http://dx.doi.org/10.2753/REE1540-496X430405

[17] Demirgüç-Kunt, A., Beck, T. and Honohan, P. (2008) Finance for All? Policies and Pitfalls in Expanding Access. The International Bank for Reconstruction and Development, World Bank, Washington DC.

[18] Fatoki, O. and Odeyemi, A. (2010) Which New Small and Medium Enterprises in South Africa Have Access to Bank Credit? International Journal of Business and Management, 5, 128-136. http://dx.doi.org/10.5539/ijbm.v5n10p128

[19] Craig, B.R., Jackson, W.E. and Thomson, J.B. (2005) The Role of Relationships in Small-Business Lending. Federal Reserve Bank of Cleveland, Cleverland.

[20] Fatoki, O. and Asah, F. (2011) The Impact of Firm and Entrepreneurial Characteristics on Access to Debt Finance by SMEs in King Williams’ Town, South Africa. International Journal of Business and Management, 6, 170-179. http://dx.doi.org/10.5539/ijbm.v6n8p170

[21] Claessens, S. and Tzioumis, K. (2006) Measuring Firms’ Access to Finance. Access to Finance: Building Inclusive Financial Systems, Washington DC, 30-31 May 2006.

[22] Irwin, D. and Scott, J.M. (2010) Barriers Faced by SMEs in Raising Bank Finance. International Journal of Entrepreneurial Behaviour \& Research, 16, 245-259. http://dx.doi.org/10.1108/13552551011042816

[23] PECC (2003) Financing Small and Medium Enterprises: Challenges and Options. A Summary Report of the Discussion at the Second Conference of PECC Finance Forum, Pacific Economic Cooperation Council (PECC), Hua Tin, Thailand, 8-9 July 2003.

[24] Mukiri, W.G. (2008) Determinants of Access to Bank Credit by Micro and Small Enterprises in Kenya. Growing Inclusive Markets Conference.

[25] El Kabbani, R.N. and Kalhoefer, C. (2001) Financing Resources for Egyptian Small and Medium Enterprises. German University in Cairo, Faculty of Management Technology, Working Study No. 28, Cairo.

[26] El-Said, H., Al-Said, M. and Zaki, C. (2013) What Determines the Access to Finance of SMEs? Evidence from the Egyptian Case. The Economic Research Forum (ERF), Dokki, Giza, Egypt.

[27] Fernando, C., Chakraborty, A. and Mallik, R. (2002) The Importance of Being Known: Relationship Banking and Credit Limits. Washington University in St. Louis, Economics Working Paper Archive at WUSTL, EconWPA (0209007), St. Luis.

[28] Beck, T. (2011) The Role of Finance in Economic Development: Benefits, Risks, and Politics. Tilburg University, Center for Economic Research, Working Paper 2011-114, Tilburg, Netherlands.

[29] Stiglitz, J. and Weiss, A. (1981) Credit Rationing in Markets with Imperfect Information. American Economic Review, 71, 393-410. 
[30] OECD (2006) The SME Financing Gap: Theory and Evidence. Volume I. Organization for Economic Co-Operation and Development (OECD), OECD Publishing, Paris. http://dx.doi.org/10.1787/9789264029415-en

[31] Aga, G.A. and Reilly, B. (2011) Access to Credit and Informality among Micro and Small Enterprises in Ethiopia. International Review of Applied Economics, 25, 313-329.

[32] Petersen, M.A. (2004) Information: Hard and Soft. Kellogg School of Management, Northwestern University, Working Paper, Chicago IL, Evanston, IL.

[33] Zhao, H., Wu, W. and Chen, X. (2006) What Factors Affect Small and Medium-Sized Enterprise's Ability to Borrow from Bank: Evidence from Chengdu City, Capital of South-Western China's Sichuan Province. Berlin School of Economics, Business Institute Berlin, Berlin, Working Paper 23, Badensche Str. 50-1, D-10825, May 2005.

[34] Kon, Y. and Storey, D. (2003) A Theory of Discouraged Borrowers. Small Business Economics, 21, 37-49. http://dx.doi.org/10.1023/A:1024447603600

[35] Zoppa, A. and McMahon, R.G.P. (2002) Pecking Order Theory and the Financial Structure of Manufacturing SMEs from Australia’s Business Longitudinal Survey. The Flinders University of South Australia, School of Commerce, Research Paper Series: 02-1, Bedford Park.

[36] Loewe, M., Al-Ayouty, I., Altpeter, A., Borbein, L., Chantelauze, M., Kern, M., Niendorf, E. and Reda, M. (2013) Which Factors Determine the Upgrading of Small and Medium-Sized Enterprises (SMEs)? The Case of Egypt. The German Development Institute (DIE) in Cooperation with the Egyptian Center for Economic Studies (ECES), Bonn.

[37] Chakraborty, A. and Mallick, R. (2010) Patterns of Debt Use in Small Businesses: A Non-Parametric Analysis. International Journal of Banking and Finance, 7, 59-78.

[38] Vesalainen, J. (1995) The Small Firms as an Adaptive Organization-Organizational Adaptation versus Environmental Selection within Environmental Change. University of Vaasa, Dissertation, Acta Wasaensia No. 42, Business Administration No. 16, Vaasa, Finland.

[39] Neneh, B.N. (2011) The Impact of Entrepreneurial Characteristics and Business Practices on the Long Term Survival of Small and Medium Enterprises (SMEs). University of Free State, Dissertation, South Africa.

[40] Islam, A., Khan, M., Aktaruzzaman, O., Abu Zafar, M. and Alam, M.S. (2011) Effect of Entrepreneur and Firm Characteristics on the Business Success of Small and Medium Enterprises (SMEs) in Bangladesh. International Journal of Business and Management, 6, 289-299.

[41] Nakano, M. and Nguyen, P. (2011) Do Older Boards Affect Firm Performance? An Empirical Analysis Based on Japanese Firms. The Sixth Annual Conference on Asia-Pacific Financial Markets (CAFM), Seoul, Korea, 2 December 2011. http://dx.doi.org/10.2139/ssrn.1879250

[42] Abdulsaleh, A.M. and Worthington, A.C. (2013) Small and Medium-Sized Enterprises Financing: A Review of Literature. International Journal of Business and Management, 8, 36. http://dx.doi.org/10.5539/ijbm.v8n14p36

[43] Slavec, A. and Prodan, I. (2012) The Influence of Entrepreneur's Characteristics on Small Manufacturing Firm Debt Financing. Journal for East European Management Studies, 17, 104-130.

[44] Kasseeah, H. and Thoplan, R. (2012) Access to Financing in a Small Island Economy: Evidence from Mauritius. Journal of African Business, 13, 221-231. http://dx.doi.org/10.1080/15228916.2012.727753

[45] Zarook, T., Rahman, M.M. and Khanam, R. (2013) Management Skills and Accessing to Finance: Evidence from Libya's SMEs. International Journal of Business and Social Science, 4, 106-115.

[46] Le, N.T.B., Venkatesh, S. and Nguyen, T.V. (2006) Getting Bank Financing: A Study of Vietnamese Private Firms. Asia Pacific Journal of Management, 23, 209-227. http://dx.doi.org/10.1007/s10490-006-7167-8

[47] Raosoft (2004) Raosoft Sample Size Calculator. Raosoft, Inc., Seattle. http://www.raosoft.com/samplesize.html

[48] Horowitz, J.L. and Savin, N. (2001) Binary Response Models: Logits, Probits and Semiparametrics. Journal of Economic Perspectives, 15, 43-56. http://dx.doi.org/10.1257/jep.15.4.43

[49] Le, P.N.M. (2012) What Determines the Access to Credit by SMEs? A Case Study in Vietnam. Journal of Management Research, 4. http://dx.doi.org/10.5296/jmr.v4i4.1838

[50] Cox, D.R., Hand, D.J. and Herzberg, A.M. (2005) Selected Statistical Papers of Sir David Cox. Cambridge University Press, Cambridge.

[51] Long, J.S. (1997) Regression Models for Categorical and Limited Dependent Variables: Advanced Quantitative Techniques in the Social Sciences. Vol. 7, Sage Publications, Thousand Oaks.

[52] Hosmer, D.W. and Lemeshow, S. (1989) Applied Logistic Regression. John Wiley \& Sons, Inc., New York. 
Scientific Research Publishing (SCIRP) is one of the largest Open Access journal publishers. It is currently publishing more than 200 open access, online, peer-reviewed journals covering a wide range of academic disciplines. SCIRP serves the worldwide academic communities and contributes to the progress and application of science with its publication.

Other selected journals from SCIRP are listed as below. Submit your manuscript to us via either submit@scirp.org or Online Submission Portal.
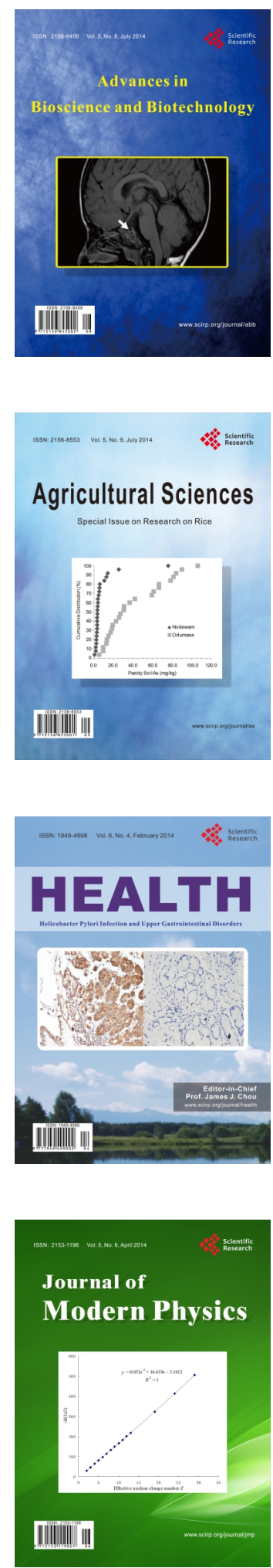
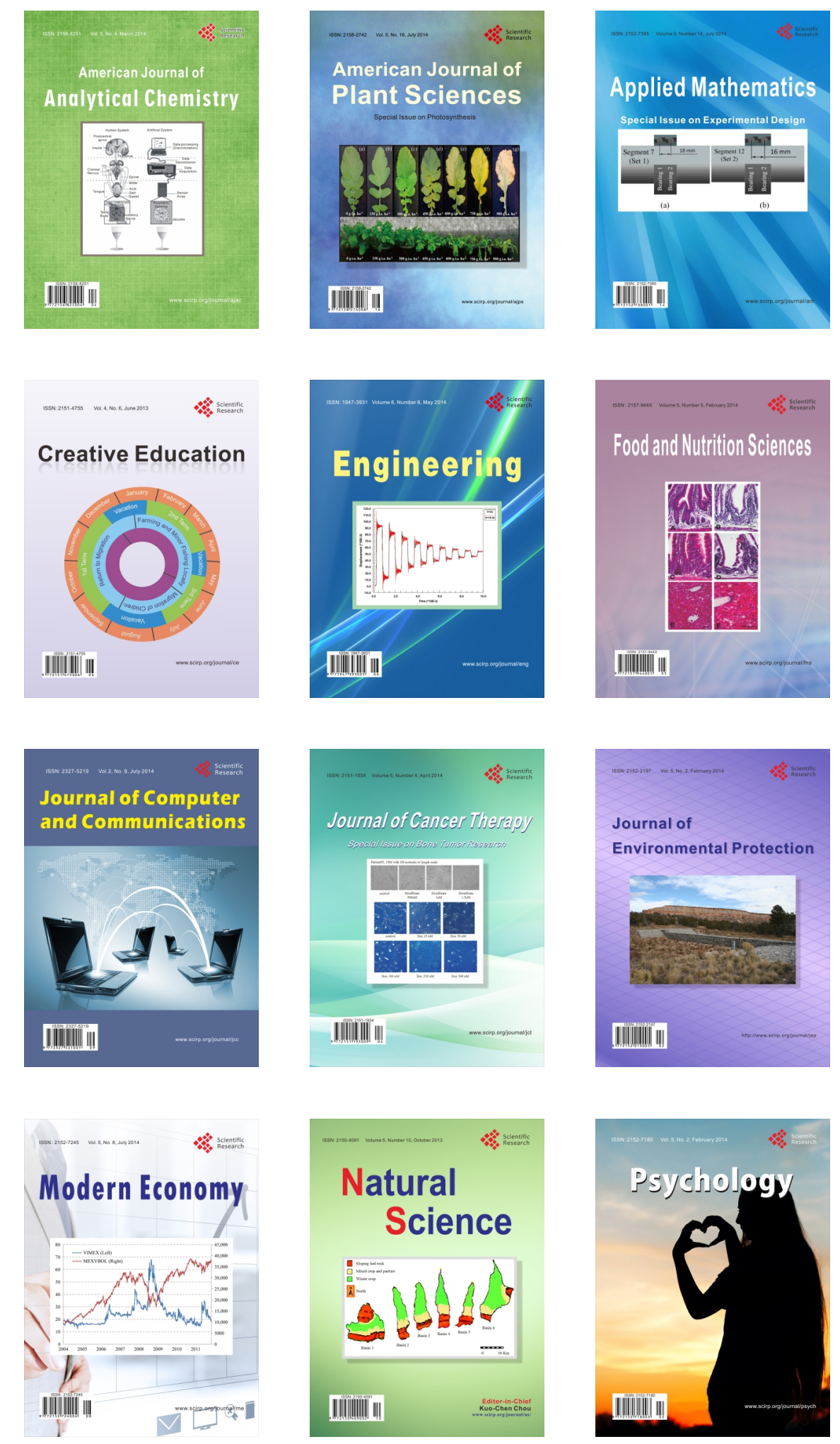